УДК 616.31-084

DOI 10.11603/24116-4944.2018.1.8806

\author{
•Ю. Б. Якимчук, В. І. Коптюх, І. М. Маланчин, Д. М. Дуве \\ ДВНЗ «Тернопільський державний медичний університет \\ ілені І. Я. Горбачевсъкого МОЗ України»
}

\title{
ПРЕГРАВІДАРНА ПІДГОТОВКА ЖІНОК, ЯКІ ПЕРЕНЕСЛИ ПОЗАМАТКОВУ ВАГITHICTЬ
}

Мета дослідження - проведення реабілітаційних заходів, які включали призначення лікувальних середників для покращення стану прохідності маткових труб та стимуляції овуляції при диссрункії яєчників після консервативного та оперативного лікування позаматкової вагітності.

Матеріали та методи. Для проведення лікувальних заходів були взяті жінки із позаматковою вагітністю за типом трубного аборту (15 жінок), у яких за даними визначення $\beta$-субодиниць ХГЛ та даними УзД були показання до призначення консервативної терапії метотрексатом за наведеною схемою. А також 15 жінок, у яких позаматкова вагітність була порушеною і лікування проводили лапароскопічним методом. Лікування прогресуючої позаматкової вагітності проводили метотрексатом 75-100 мл внутрішньом'язово при показниках ß-ХГЛ більше 1500 МО/л, за даними УзД - діаметр плідного яйця не більше 3,5 см у ділянці придатків матки. Додатково для усунення побічних явищ та впливу на печінку призначали гепатопротектори та фоолати. Контроль за динамікою лікування здійснювали повторним визначенням $\beta$-ХГЛ. Якщо він знижувався більше ніж на 15 \%, то повторно метотрексат не вводили, у випадку меншого зниження проводили повторне введення метотрексату. Виписку хворої із стаціонару здійснювали на 8-10 добу під контролем УЗД та показників $\beta$-ХГЛ. Хворим із II групи проводили лапароскопічне видалення плідного яйця: туботомію з неосальпінгостомією.

Результати дослідження та їх обговорення. Відновлення репродуктивної фрункції проводили за даними визначення в сироватці крові ФСГ, прогестерону та пролактину. 3 метою прегравідарної підготовки застосовували фрітопрепарати екстракту плодів прутняку (циклодинон, мастодинон) та фолати. У післяопераційному періоді проводили призначення моносразних контрацептивів протягом 3-х менструальних циклів із подальшим визначенням прохідності маткових труб. Під час проведення консервативного лікування позаматкової вагітності та комплексу заходів для відновлення репродуктивної фрункції протягом трьох менструальних циклів маткова вагітність настала в 6-ти жінок протягом 6-ти місяців після прегравідарної підготовки. Ще у 6-ти жінок вагітність настала протягом одного року при включенні повторного курсу гормональної корекції після шестимісячної перерви й у 3-х жінок не вдалося досягнути позитивного результату. У II групі жінок, у яких було проведено оперативне лікування позаматкової вагітності, в комплекс прегравідарної підготовки включали призначення монофазних контрацептивів протягом 3-х місяців та проведення контрольної МСг на прохідність маткових труб. Прегравідарна підготовка включала проведення комплексу заходів, які сприяли відновленню прохідності маткових труб, та однофазні гормональні контрацептиви. У результаті проведених реабілітаційних заходів та прегравідарної підготовки вагітність настала у 33 \% обстежених жінок у перші 12 місяців.

Висновки. Проведення консервативного лікування ПВ із збереженням маткової труби дозволило досягти настання вагітності в більш ранні терміни проведення реабілітаційних заходів для виконання репродуктивної фрункції в жінок, які перебували під нашим спостереженням. Призначення фрітокомплексу (циклодинон) та фолієвої кислоти для корекції гормональної дисорункції дозволяє отримати настання вагітності та її виношування у 33 \% обстежених жінок.

Ключові слова: позаматкова вагітність; метотрексат; лапароскопія; прегравідарна підготовка.

ПРЕГРАВИДАРНАЯ ПОДГОТОВКА ЖЕНЩИН, ПЕРЕНЕСШИХ ВНЕМАТОЧНУЮ БЕРЕМЕННОСТЬ

Цель исследования - проведение реабилитационных мероприятий, которые включали назначение комплекса мероприятий для улучшения состояния проходимости маточных труб и стимуляции овуляции при диссункции яичников после консервативного и оперативного лечения внематочной беременности.

Материалы и методы. Для проведения лечебных мероприятий были взяты женщины с внематочной беременностью по типу трубного аборта (15 женщин), у которых по данным определения ß-субъединиц ХГЧ и данным УзИ было показано назначение консервативной терапии метотрексатом по приведенной схеме. А также 15 женщин, у которых внематочная беременность была нарушенной и лечение проводилось лапароскопическим методом. Лечение прогрессирующей внематочной беременности проводилось метотрексатом 75-100 мл внутримышечно при показателях $\beta$-ХГЧ более 1500 МЕ/л, по данным УзИ - диаметр плодного яйца не более 3,5 см в области придатков матки. Дополнительно для устранения побочных явлений и воздействия на печень назначались гепатопротекторы и фолаты. Контроль за динамикой лечения осуществлялся повторным определением ß-ХГЧ. При снижении более чем на 15 \% повторно метотрексат не вводился. В случае меньшего снижения проводилось повторное введение метотрексата. Выписка больной из стационара осуществлялась на 8-10 сутки под контролем УзИ и показателей ß-ХГЧ. Больным II группы проводилось лапароскопическое удаление плодного яйца: туботомия с неосальпингостомией.

Результаты исследования и их обсуждение. Восстановление репродуктивной суункции проводилось по данным определения в сыворотке крови ФСГ, прогестерона и пролактина. С целью прегравидарной подготовки применялись фритопрепараты экстракта плодов прутняка (циклодинон, мастодинон) и фролаты. В послеоперационном периоде проводилось назначение моносразных контрацептивов в течение 3 менструальных циклов с последующим определением проходимости маточных труб. Во время проведения консервативного лечения внематочной беременности и комплекса мер по восстановлению репродуктивной фуункции в течение трех менструальных циклов маточная беременность наступила у 6-ти женщин в течение 6 месяцев после прегравидарной подготовки. Еще у 6-ти женщин беременность наступила в течение одного года при включении повторного курса гормональной коррекции 
после шестимесячного перерыва и у 3-х женщин не удалось достичь положительного результата. Во второй группе женщин, у которых было проведено оперативное лечение внематочной беременности, в комплекс прегравидарной подготовки включали назначение монофазных контрацептивов в течение 3-х месяцев и проведение контрольной МсГ на проходимость маточных труб. Прегравидарная подготовка включала проведение комплекса мероприятий, которые способствовали восстановлению проходимости маточных труб, и однофазные гормональные контрацептивы. В результате проведенных реабилитационных мероприятий и прегравидарной подготовки беременность наступила у 33 \% обследованных женщин в первые 12 месяцев.

Выводы. Проведение консервативного лечения ВБ с сохранением маточной трубы позволило достичь наступления беременности в более ранние термины проведения реабилитационных мероприятий для выполения репродуктивной срункции у женщин, находящихся под нашим наблюдением. Назначение фритокомплекса (циклодинон) и фролиевой кислоты для коррекции гормональной дисфункции позволяет получить наступление беременности и ее вынашивание в 33 \% обследованных женщин.

Ключевые слова: внематочная беременность; метотрексат; лапароскопия; прегравидарная подготовка.

\section{PREGRAVID PREPARATION IN WOMEN WHO UNDERWENT ECTOPIC PREGNANCY}

The aim of the study - to carry out rehabilitation measures, which included the appointment of therapeutic agents to improve the status of fallopian tubes and stimulate ovulation in ovarian dysfunction after conservative and surgical treatment of ectopic pregnancy.

Materials and Methods. For medical treatment, women with an ectopic pregnancy were taken on the type of tubal abortion (15 women), in whom, according to the definition of $\beta$-subunits of HCG and data of ultrasound scan, there were indications for prescribing conservative methotrexate therapy by the scheme. As well as 15 women who had an ectopic pregnancy and treatment was carried out by the laparoscopic method. Treatment of progressive ectopic pregnancy was carried out by methotrexate $75-100$ ml intramuscularly with indicators B CGL more than 1500ME / I, according to ultrasound - the diameter of the fetal egg is not more than $3.5 \mathrm{~cm}$ in the area of the uterus appendages. In addition, geneotoprotectors and folate were prescribed for elimination of side effects and effects on the liver. Control over the dynamics of treatment was carried out by redefining $\beta$-HGL. If it decreases by more than $15 \%$, then methotrexate is not re-administered again, in the case of a lower reduction, repeated administration of methotrexate was carried out. An extract of the patient from the hospital was carried out for 8-10 days under the control of ultrasound and indicators of $\beta$-HGL. Patients from the 2nd group carried out laparoscopic removal of the fetal egg: tubotomy with neosalpingodomy.

Results and Discussion. Restoration of reproductive function was carried out according to data defined in serum, FSH, progesterone and prolactin. For the purpose of pre-glare preparation phytopreparations of the fruit extract of the willow shrubbery (Cyclodinone, Mastodinon) and folate were used. In the postoperative period, the appointment of monophasic contracents during the 3 menstrual cycles followed by the determination of the patency of the fallopian tubes. During conservative treatment of ectopic pregnancy and a set of measures to restore reproductive function during three menstrual cycles, uterine pregnancy occurred in 6 women within 6 months of pre-admission training. In 6 women, pregnancy occurred within one year with the inclusion of a second course of hormonal correction after a six-month break, and 3 women failed to achieve a positive result. In the 2 nd group of women who had surgical treatment of ectopic pregnancy in the complex of pre-bladder training, they included the appointment of monophasic contraceptives for 3 months and control of MSG for the passage of fallopian tubes. Pregravid training included a series of activities that contributed to the restoration of patency of the fallopian tubes and single-phase hormonal contraceptives. As a result of rehabilitation and pre-glare preparation, pregnancy occurred in $33 \%$ of surveyed women in the first 12 months.

Conclusions. Conducting conservative treatment of EP with preservation of the uterine tube allowed to achieve pregnancy in earlier terms of carrying out rehabilitation measures for performing reproductive function in women under our supervision. The purpose of the phytocomplex (cyclodinone) and folic acid for correction of hormonal dysfunction allows to get pregnancy and its bearing in $33 \%$ of the examined women.

Key words: ectopic pregnancy; methotrexate; laparoscopy; pregravid training.

ВСТУП. На сучасному етапі у вирішенні питання безпліддя позаматкова вагітність займає одне з перших місць. По-перше, це пов'язано із виникненням ускладнень, які виникають після оперативного лікування позаматкової вагітності, такими, як: розвиток спайкового процесу в малому тазу, гормональні порушення, які виникають при дисфрункції яєчників [2, 3]. Одним із найбільш болючих моментів для жінки, яка перенесла оперативне втручання, пов'язане із позаматковою вагітністю, - це настання маткової вагітності і її виношування. Безпліддя, пов'язане із порушенням прохідності маткових труб, залишається значним і складає 32 \%, в той же час безпліддя, пов'язане з гормональними порушеннями, становить $42 \%$ [2-4]. За останні 10 років стали віддавати перевагу консервативному лікуванню ПМВ, а саме призначенню метотрексату [4-6].

МЕТА ДОсЛІДЖЕНня - проведення реабілітаційних заходів, які включали призначення лікувальних середників для покращення стану прохідності маткових труб та стимуляції овуляції при дисфункції яєчників після консервативного та оперативного лікування позаматкової вагітності.
МАТЕРІАЛИ ТА МЕТОДИ. Для дослідження було обстежено і проліковано 30 жінок із прогресуючою позаматковою вагітністю за типом трубного аборту та 3 порушеною позаматковою вагітністю за типом розриву труби. Лікування та діагноз проводили за даними УЗД трансвагінальним датчиком та визначенням $\beta$-субодиниці ХГЛ у сироватці крові. Лікування прогресуючої позаматкової вагітності проводили метотрексатом 75-100 мл

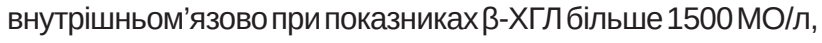
за даними УЗД - діаметр плідного яйця не більше 3,5 см у ділянці придатків матки [1].

Під спостереженням перебували 30 жінок, які лікувалися з приводу позаматкової вагітності.

I група - 15 жінок, із приводу прогресуючої позаматкової вагітності за типом трубного аборту та II група - 15 жінок із порушеною позаматковою вагітністю за типом розриву маткової труби, у яких проводили лапароскопічне видалення плідного яйця.

Першовагітних жінок в обох групах, відповідно, 30 \% (10 жінок) і 22 \% (11 жінок). 
У І групі переважали жінки із порушеннями менструального циклу, гіпоменструальний синдром був у 8 жінок (52 \%). У II групі більшість склали жінки із трубним непліддям - 7 жінок (48 \%), порушення менструального циклу було у 4 жінок (22 \%) та у 2 жінок (6,6 \%) була ВМС.

Жінкам I групи призначали метотрексат 100 мг внутрішньом'язово.

Додатково для усунення побічних явищ та впливу на печінку призначали гепатопротектори та фолати. Контроль за динамікою лікування здійснювали повторним визначенням $\beta$-ХГЛ. Якщо він знижувавня більше ніж на $15 \%$, то повторно метотрексат не вводили, у випадку меншого зниження проводили повторне введення метотрексату.

Виписку хворої із стаціонару здійснювали на 8-10

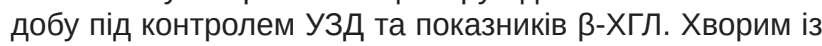
II групи проводили лапароскопічне видалення плідного яйця: туботомію з неосальпінгостомією.

РЕЗУЛЬТАТИ ДОСЛІДЖЕННЯ ТА ЇХ ОБГОВОРЕН-

ня. Відновлення репродуктивної функції проводили за даними визначення в сироватці крові ФСГ, прогестерону та пролактину.

У післяопераційному періоді проводили призначення монофазних контрацептивів протягом 3-х менструальних циклів із подальшим визначенням прохідності маткових труб.

У I групі жінок, лікованих метотрексатом, проводили реабілітаційну терапію препаратами фолієвої кислоти та орітопрепаратами екстракту плодів прутняку (циклодинон, мастодинон) протягом 3-х місяців 3 метою прегравідарної підготовки репродуктивної функції до подальших вагітностей. У випадку недостатності лютеїнової фрази в комплекс прегравідарної підготовки включали гестагенні препарати, при порушенні менструальної фрункції - монофразні контрацептиви протягом 3-х місяців [2, 4].

\section{СПИСОК ЛІТЕРАТУРИ}

1. Наказ МОЗ України № 676 «Про затвердження клінічних протоколів 3 акушерської та гінекологічної допомоги». - К., 2004. - С. 106-116.

2. Камінський В. В. Сучасні етіологічні фрактори позаматкової вагітності / В.В.Камінський, Ю.О. Туренко // Буковинський медичний вісник. - 2003. - Т. 7, № 4. - С. 176-178.

3. Methotrexate - the success rate for a progressive ectopic pregnancy: a new assessment / Z. L. Koén, U. Dzhyl, Z. H. Amer-Alshiek [et al.] // Am. J. Obstet. Gynecol. - 2014. - Vol. 211 (2). - P. 141-147. doi: 10.1016/j.ajog.2014.03.043.

\section{REFERENCES}

1. (2004). Nakaz MOZ Ukrainy № 676 Pro zatverdzhennia klinichnykh protokoliv z akusherskoi ta hinekolohichnoi dopomohy [Order of the Ministry of Health of Ukraine No. 676 on Approval of Clinical Protocols on Obstetric and Gynecological Aid]. Kyiv [in Ukrainian].

2. Kaminskyi, V.V., \& Turenko, Yu.O. (2003). Suchasni etiolohichni faktory pozamatkovoi vahitnosti [Modern etiological factors of ectopic pregnancy]. Bukovynskyi medychnyi visnyk - Bukovynian Medical Journal, 7, 4, 176178 [in Ukrainian].

3. Koén, Z.L., Dzhyl, U., Amer-Alshiek, Z.H., Bibi, Z.H., Almog, V., \& Levin, I. (2014). Methotrexate - the success rate
Під час проведення консервативного лікування позаматкової вагітності та комплексу заходів для відновлення репродуктивної фрункції протягом трьох менструальних циклів маткова вагітність настала у 6-ти жінок протягом 6-ти місяців після прегравідарної підготовки. ще у 6-ти жінок вагітність настала протягом одного року при включенні повторного курсу гормональної корекції після шестимісячної перерви і у 3-х жінок не вдалося досягнути позитивного результату.

У II групі жінок, у яких було проведено оперативне лікування позаматкової вагітності, в комплекс прегравідарної підготовки включали призначення монофразних контрацептивів протягом 3-х місяців та проведення контрольної МСГ на прохідність маткових труб. Прегравідарна підготовка включала проведення комплексу заходів, які сприяли відновленню прохідності маткових труб.

Вагітність дозволялася через 6 місяців після оперативного лікування, що відтерміновувало настання вагітності. Так, через 12 місяців вагітність настала в 4-х жінок, ще через 12 місяців - ще у 5-ти. Вагітність не настала в 6-ти жінок.

ВИСНОВкИ. Таким чином, проведення консервативного лікування ПВ із збереженням маткової труби дозволило досягти настання вагітності в більш ранні терміни проведення реабілітаційних заходів для виконання репродуктивної функції в жінок, які перебували під нашим спостереженням.

Призначення фрітокомплексу (циклодинон) та фролієвої кислоти для корекції гормональної дисфрункції дозволяє отримати настання вагітності та її виношування у 33 \% обстежених жінок.

ПЕРСПЕКТИВИ ПОДАЛЬШИХ ДОСЛІДЖЕНЬ. На СУчасному етапі лікування позаматкової вагітності вимагає подальшого спостереження за виконанням репродуктивної фрункції в жінок дітородного віку з метою настання та виношування вагітності.

4. Маркін С. Б. Позаматкова вагітність / С. Б. Маркін, О. О. Матвієнко, С. А. Маркін. - Львів, 1999. - 106 с.

5. Systemic methotrexate : An effective alternative to surgery for management of unruptured ectopic pregnancy / R. Talvar, K. Sandip, N. Naredi [et al.] // Med. J. Armed Forces of India. 2013. - Vol. 69 (2). - P. 130-133. doi: 10.1016/j.mjafi.2012.08.032.

6 . Prognostic value of early hCG changes after methotrexate injection for ectopic pregnancy / P. Bottin, A. Gnisci, P. Crochet [et al.] // Gynecol. Obstet. Fertil. - 2014. - Vol. 42 (1). - P. 3-7.

for a progressive ectopic pregnancy: a new assessment. Am. J. Obstet. Gynecol., 141-147.

4. Markin, S.B., Matviyenko, O.O., \& Markin, S.A. (1999). Pozamatkova vahitnist [Ectopic Pregnancy]. Lviv [in Ukrainian]. 5. Talvar, R., Sandip, K, Naredi, N. Duggal, B.C., \& Khose, T. (2013). Systemic methotrexate: an effective alternative to surgery for management of unruptured ectopic pregnancy. Med. J. Armed Forces of India, 69 (2), 130-133. doi: 10.1016/j. mjafi.2012.08.032.

6. Bottin, P., Gnisci, Cravello, L., Gamerre, M., \& Agostini, A. (2014). Prognostic value of early hCG changes after methotrexate injection for ectopic pregnancy. Gynecol. Obstet. Fertil., 42 (1), 3-7.

Отримано 05.02.18 